\title{
SYNTHESIS OF BENIGN SILVER NANOPARTICLES TO ENHANCE ANTIBACTERIAL ACTIVITY OF AZADIRACHTA INDICA
}

\author{
Sushmita Kundu, Ayesha Ashraf and Ahsan Habib* \\ Biotechnology and Genetic Engineering Discipline, Khulna University, Khulna-9208, Bangladesh
}

http://doi.org/10.35410/IJAEB.2019.4466

\begin{abstract}
Biologically synthesized nanomaterials and their industrial utilization have become an integral part of bionanotechnology. There is an increasing demand for silver nanoparticles (Ag-NPs) due to its wide properties in various fields of biomedical science including bio-sensing, drug delivery etc. Thus, the aim of the current study was to synthesize Ag-NPs by reducing the silver ions present in the silver nitrate (AgNO3) solution by green method to enhance antibacterial activity of a common medicinal plant Azadirachta indica. Initially, pure cultures of four gram positive $(\mathrm{gm}+\mathrm{ve})$ and eight gram negative (gm -ve) pathogenic bacteria were evaluated against the crude plant (leaf and bark) extracts and based on their susceptibility, two gm +ve and four gm -ve bacterial strains were finally selected. In case of crude extract, the highest zone of inhibition $(13.00 \pm 1.00 \mathrm{~mm})$ was observed against Staphylococcus aureus when treated with leaf samples, whereas it was $14.83 \pm 2.26 \mathrm{~mm}$ when treated with barks. Afterwards, Ag-NPs has been synthesized following greener method and the formation of Ag-NPs was confirmed by visual observation (colour change from pale yellow to dark brown) followed by Ultra-Violet Visible (UV-VIS) spectroscopy. Later, plant extracts with synthesized Ag-NPs were tested against same six bacterial strains and the obtained zone of inhibitions were compared with those of crude extract. As expected, both leaf and bark extracts showed increased zone of inhibition than previous. In this case, the diameter of the highest zone of inhibition was found $27.33 \pm 1.36 \mathrm{~mm}$ against $S$. aureus when treated with leaf extracts containing Ag-NPs and it was30.00 $\pm 2.60 \mathrm{~mm}$ against the same bacterial strain. In case of bark extract with Ag-NPs. Finally, minimum inhibitory concentration (MIC) test was performed using both crude and Ag-NPs containing plant extracts. Significant differences were observed in MIC values between both types of plant extracts. The MIC value was found $0.312 \mathrm{mg} / \mathrm{ml}$ for both crude leaf and bark extracts and 0.078 $\mathrm{mg} / \mathrm{ml}$ and $0.039 \mathrm{mg} / \mathrm{ml}$ for leaf and bark extract containing Ag-NPs, respectively. So, it could be concluded that the eco-friendly A. indica extracts (leaf and bark) can be used as an effective reducing agent for the synthesis of Ag-NPs and thus the antimicrobial activity of the selected medicinal plant can be enhanced by synthesized nanoparticles.
\end{abstract}

Keywords: Bionanotechnology, Silver nanoparticles (Ag-NPs), Azadirachta indica, Antibacterial activity, Zone of inhibition (ZOI).

\section{INTRODUCTION}

Silver $(\mathrm{Ag})$ is familiar worldwide for its antimicrobial activity which was first identified in the 19th century (Hugo WB et al., 1982 \& Teot L et al., 2005). In recent times, silver nanoparticles 
(Ag-NPs) became one of the most investigated and commercialized nano-materials as it has auspicious characteristics appropriate for various biomedical applications (Lugli $\mathrm{P}$ et al., 2005;Karni TC et al., 2012 \& Ahmed S et al., 2014). Different preparation approaches have been devised and applied in the synthesis of nanoparticles of several materials, such as metallic (Murphy CJ et al., 2005; Ledwith D M et al., 2009 \&Yu CH et al., 2009), dielectric (Nelson JK., 2007 \& Baklanov MR, 2012), semiconductor (Zhang JZ et al., 2004 \& Weber C et al., 2008) and magnetic (Lu A et al., 2007 \& Koksharov YA, 2009). However, the rigorous usage of solvents and synthetic reactants is detrimental for the environment. For this reason, it is very prudential to devise alternative methods of nanomaterial preparation that use environment-friendly reactants. Different bioactive compounds (flavonoids, terpenoids etc.) found in plant extracts have made them suitable for the green synthesis of nanoparticles (Atawodi SE et al., 2009). The synthesis of Ag-NPs using different plant extracts can be an alternative and effective choice as it is simple, cost-effective, environment friendly and relatively reproducible and often results in more stable materials (Ahmed S et al., 2015 \& Mittal J et al., 2014).

In recent times, there is a growing interest in the synthesis of metal nanoparticles by using extracts from different plants (Niraimathi KL et al., 2013; Sharma VK et al., 2009; Vankar PS et al., 2012; Narayanan KB et al., 2011; Singh S et al., 2013; Das S et al., 2013; Suriyakalaa U et al., 2013; Mohanpuria P et al., 2008; Gardea-Torresdey JL et al., 2008; Armendariz V et al., 2004; Kumar VG etal., 2011; Ghoreishi SM et al., 2011; Dubey SP et al., 2011; Lahtinen M et al., 2010; Shankar SS et al., 2003; Rai A et al., 2004; Parsons JG et al., 2007; Dubey SP et al., 2010 \& Noruzi M et al., 2012). In our study, extracts from Azadirachta indica were used as reducing agents. The use of $A$. indica plant for the production of silver nanoparticles has drawn our attention as it is one of the most common medicinal plants in Bangladesh and other regions of South Asia. Also, it does not require addition of external stabilizing agent during synthesis of nanoparticles (Tripathi A et al., 2009). Moreover, the plant is rich in quercetin and B-sitosterol, polyphenolic flavonoids, and well known to have antibacterial and antifungal properties (Govindachari TR et al., 1998; Girish, 2008 \& Alzohairy MA, 2016).

Thus, in the present study, at first we synthesized silver nanoparticles using leaf and bark extracts of $A$. indica. We have characterized the resulting nanoparticles by ultraviolet-visible (UV-Vis) spectroscopy and minimum inhibition test (MIC).Finally, we evaluated and compared antimicrobial activity of both plant extracts with and without Ag-NPs. To the best of our knowledge, this is the first report in the literature on nanoparticle synthesis for enhancing antibacterial activity using this plant.

\section{MATERIALS AND METHODS}

\subsection{Collection and preparation of plant extracts}

The fresh A. indica leaves and barks were collected from Khulna University campus, Khulna, Bangladesh and safely taken to laboratory for further experimental analysis. Collected leaves and barks were carefully cleaned and sliced into small pieces. The sliced plant materials were dried under sunshade and air for several weeks. After the completion of drying, the plant materials were grounded into powder with a grinder machine. The powder was weighted and soaked into $50 \%$ ethyl acetate $(50 \mathrm{~g}$ powder within $100 \mathrm{ml}$ ethyl acetate) individually. They were then sealed 
and kept for 168 hours in a dark room accompanying occasional shaking and stirring. Finally, the mixtures were filtered with meracloth and stored at $4^{0} \mathrm{C}$ until for next experiment.

\subsection{Green synthesis of $\mathrm{Ag}$ nanoparticles}

Silver nitrate salt (AgNO3 M.W. 169.88) was used for the synthesis of silver nanoparticles. For preparation of $300 \mathrm{ml}$ silver nitrate solution, $0.0507 \mathrm{~g}$ silver salt was dissolved in distilled water by continuous stirring with the help of magnetic stirrer for $5 \mathrm{~min}$. Then the solution container was sealed with foil paper and kept into a dark place to avoid reduction reaction. $50 \mathrm{ml}$ of freshly prepared $1 \mathrm{mM}$ silver nitrate solution was added to $5 \mathrm{ml}$ of each sample solution (leaf and bark extracts). Then the mixture was exposed into direct sunlight to drive nanoparticle formation for about 30 min until visible colour change (brown colour) was observed.

\subsection{Characterization by UV-Vis Spectral analysis}

The UV-VIS spectroscopy was used to examine the reduction of $\mathrm{Ag}+$ from $\mathrm{AgNO}_{3}$ and finally to confirm the biosynthesis of silver nanoparticles and the absorbance was measured from 0min of preparing the reaction mixture to 120 min with the regular interval of 30 minutes at different wavelengths (300nm to $700 \mathrm{~nm}$ ).

\subsection{Antibacterial activity tests}

The in vitro antibacterial activity of plant extracts with and without silver nanoparticles was assessed quantitatively by disc diffusion assay and the results were validated by determining the Minimum Inhibitory Concentration (MIC) values of test samples. For disc diffusion assay, 24hrs old grown bacterial subcultures were inoculated in nutrient broth and poured into petri plates containing Muller Hinton Agar (MHA) media (HiMedia Laboratories) and were spread gently with a sterile spreader. Antibacterial activity of the samples was tested against four gram positive and eight-gram negative pathogenic bacterial isolates (Table 1). These bacterial cultures were previously isolated and characterized by Microbiology Laboratory, Biotechnology and Genetic Engineering Discipline, Khulna University, Bangladesh. Then the sample discs (concentration for leaf were $45 \mu \mathrm{g} / \mathrm{disc}$ and $90 \mu \mathrm{g} / \mathrm{disc}$ and for bark were $30 \mu \mathrm{g} / \mathrm{disc}$ and $60 \mu \mathrm{g} / \mathrm{disc}$ ), antibiotic disc $(20 \mu \mathrm{l} / \mathrm{disc})$ as a positive control and blank disc (negative control) were inserted on the spread plates and kept into incubator for $24 \mathrm{hrs}$ at $37^{\circ} \mathrm{C}$. The diameter of the zone of inhibition (ZOI) was measured and the mean value was calculated.

To support the results obtained from disc diffusion assay, minimum inhibitory concentration (MIC) assay was performed by micro broth dilution method. Briefly, at first stock solution was prepared by dissolving plant extract in 10\% dimethyl sulfoxide (DMSO) to make a final concentration of $20 \mathrm{mg} / \mathrm{ml}$. Eight Eppendorf tube $(2 \mathrm{ml})$ were taken for MIC assay. In the first tube $1 \mathrm{ml}$ of stock solution were taken and in other tubes $0.5 \mathrm{ml}$ of broth supplemented with glucose and phenol red. For micro dilution, $0.5 \mathrm{ml}$ of stock from the first tube was transferred to $0.5 \mathrm{ml}$ broth on the next tube, and then serially diluted to rest of the tubes. Then, $10 \mu \mathrm{l}$ of bacterial suspension $\left(4.5 \times 10^{5} \mathrm{cfu} / \mathrm{ml}\right)$ was added to each tube and placed in an incubator at $37^{\circ} \mathrm{C}$ for 18 $24 \mathrm{hrs}$. After the incubation period, colour change of the mixture tube was assessed visually. Any colour changes from red to yellow or colourless were recorded as positive. The lowest 
concentration at which colour change occurred was taken as the MIC value. The average of three values was calculated and that was the MIC for the test material and bacterial strain.

\section{RESULTS AND DISCUSSION}

Present study was conducted with a view to synthesize Ag-NPs by means of a biological method (green method) and then assess its impact on the antibacterial activity of a medicinal plant.

\subsection{Synthesis and confirmation of nanoparticles}

For small scale formation of Ag-NPs, plant (leaf and bark) extracts were prepared using 50\% ethyl acetate and then kept under sunlight for the formation of Ag-NPs. The formation of nanoparticles was initially confirmed by visual observation (colour change) and finally by UVVis Spectroscopy. After $30 \mathrm{~min}$ exposure, visible colour change (from transparent to dark brown) was observed which indicated the formation of silver nanoparticles (Figure 1) (Syafiuddin A et al., 2017). This colour change occurred due to the reduction of silver ions by terpenoids (Azadirachtin, nimbin, nimbidin) and flavonoids (quercetin) present in the plant extracts (Atawodi SE et al., 2009). Since the leaf and stem of A. indica contains polyphenols, it was anticipated that the plant extracts would serve as reducing agent for nanoparticle synthesis. Actually, the same molecular mechanisms that give antioxidant properties to these molecules must promote the reduction of Ag+ ions to Ag atoms (Ericka RL et al., 2013). The main mechanism is hydrogen abstraction (Sivaraman SK et al., 2009) due to the $\mathrm{OH}$ groups in the polyphenol molecules. Finally, after 120 minutes, there was no change in the intensity of colour development, which indicated the completion of reduction reaction.

The change in colour, and thus the formation of silver nanoparticles, was confirmed by the UVVis experiments. For UV-VIS spectral analysis, absorbance bands of the samples were recorded in the range of 300 to $700 \mathrm{~nm}$ at five time intervals $(0,30,60,90$ and $120 \mathrm{~min})$. At the beginning of the reaction, the absorbance of the mixture was 0 as there were no synthesis occurred. With the increase of time, the absorbance of samples also increased gradually indicating the formation and increasing concentration of Ag-NPs. The intensity of the peaks (for both leaf and bark extracts) were recorded highest around $400 \mathrm{~nm}$. The UV-Vis peak is more pronounced for higher AgNO3 concentrations (Fig $2 \& 3$ ), indicating that more nanoparticles per unit volume are formed when this concentration increases (Ericka RL et al., 2013). The UV-VIS absorption spectrum gave a characteristic surface plasmon resonance absorption band centred at $400 \mathrm{~nm}$. The shape of the plasmon bands were almost symmetrical suggesting well-dispersed and uniform-sized nanoparticle synthesis (Tran QH et al., 2013). The overall band patterns indicated that the Ag-NPs prepared by leaf extract were very stable without aggregation.

\subsection{Antibacterial activity of plant extracts with and without Ag-NPs:}

Initially 12 bacterial isolates (Table 1) were used to assess antibacterial activity of crude leaf and bark extracts. Among these isolates, two gram positive (Micrococcus and Staphylococcus aureus) and four gram negative (E. coli, Vibrio cholerae, Salmonella typhi and Proteus vulgaris) isolates were selected based on their susceptibility against the test plant samples. The selected bacterial isolates showed prominent and better zone of inhibition compared to others. These 6 bacterial isolates were then used for further assessment of plant extracts with and without $\mathrm{Ag}$ NPs. 
Among the 6 bacterial isolates, S. aureus (gram negative) showed highest zone of inhibition in case of both plant extracts. The diameter of zone of inhibition was $13.00 \pm 1.00 \mathrm{~mm}$ when it $(S$. aureus) treated with leaf extracts and $14.83 \pm 2.26 \mathrm{~mm}$ with bark extracts. Later, antibacterial activity of both plant extracts and synthesized Ag-NPs were tested against previously used 6 bacterial isolates. Enhancement of antimicrobial activity by addition of Ag-NPs was also reported before with other plant extracts (Tahany GM et al., 2015; Prasad TN et al., 2011; Moyo M et al., 2015; Satish V Patil et al., 2012 \& Dobrucka R et al., 2015). In this experiment, synthesized Ag-NPs significantly enhanced the antibacterial activity of both plant extracts against all tested bacteria. Among all tested bacteria, S. aureus showed highest zone of inhibition compared to others when treated with plant extracts. In case of leaf extract, Ag-NPs increased the diameter of zone of inhibition by $14.33 \pm 0.36 \mathrm{~mm}$. Similarly, in case of bark extract, nanoparticles increased the diameter of zone of inhibition by $15.17 \pm 0.34 \mathrm{~mm}$. However, in comparison to leaf and bark extracts, bark extract was found more effective than leaf against all tested microorganisms (Figure $5 \& 6$ ).

For further confirmation of the above-mentioned effects of Ag-NPs, MIC test was performed with all samples against the same bacterial isolates. MIC value was significantly low (0.078 $\mathrm{mg} / \mathrm{ml}$ and $0.039 \mathrm{mg} / \mathrm{ml}$ for leaf and bark extract respectively) containing nanoparticles compared to that $(0.312 \mathrm{mg} / \mathrm{ml})$ of only crude plant extracts (Table 4). Thus, presence of Ag-NPs in both plant samples enhanced their antibacterial activity to a significant level.

\section{CONCLUSION}

Synthesis of nanoparticles is of current interest for applications such as catalysis, electronics ( $\mathrm{Lu}$ Wet al., 2007; Lugli P et al., 2010; Karni TC et al., 2012 \& Mitin VV et al., 2008), photonics (Shen Yet al., 2000; Zalevsky Z et al., 2009 \& Taylor A, 2008), catalysis (Kalidindi SB et al., 2012; Serp P et al., 2013 \& Kung HH et al., 2007), medicine (Shomura Y, 2011; Jotterand F et al., 2011; Lee H et al., 2007; Etheridge ML et al., 2013 \& Mata A et al., 2012) etc. This increasing demand must be accompanied by "green" synthesis methods to reduce globally generated hazardous wastes. Here in this experiment, we strived to synthesize Ag-NPs by means of biological (green) method. We have prepared silver nanoparticles using extracts of $A$. indica, a plant abundantly found in Bangladesh, as reducing agent. The results are very promising since the extract promotes the formation of nanoparticles at room temperature with a fast kinetics and with no harmful chemicals. Our method is easy to perform in a single step. UV-Vis spectroscopy experiments show that $A$. indica is a plant rich in polyphenols, such as catechines and stilbenes, molecules that have antioxidant activity. The same molecular mechanisms responsible of the antioxidant activity allow the use of these molecules as reducing agents and stabilizing effects for silver nanoparticles. The silver nanoparticles synthesized by this method are strong candidates for its use in biological systems. The silver nanoparticles obtained by this method definitely opened a new route to study catalytical activity, antimicrobial properties, and the optical response of this nanomaterial.

Emergence of resistance to multiple antimicrobial agents in pathogenic bacteria has become a significant public health threat as there are fewer, or even sometimes no, effective antimicrobial agents available for infections caused by these bacteria. Gram-positive and Gram-negative 
bacteria are both affected by the emergence and rise of antimicrobial resistance (Govindachari TR et al., 1998). The synthesized silver nanoparticles showed efficient antimicrobial activities against both gram positive and negative bacterial isolates. Benefits of using plant extract for synthesis is that it is energy efficient, cost effective, protecting human health and environment leading to lesser waste and safer products. This eco-friendly method could be a competitive alternative to the conventional physical/chemical methods used for synthesis of silver nanoparticle and thus has a potential to use in biomedical applications and will play an important role in opto-electronics and medical devices in near future.

\section{ACKNOWLEDGEMENTS}

Work reported in this publication was partially supported by Khulna University Research Cell, Bangladesh (Project number KURC-RGP-13/2018). We thank the anonymous referees for critical reading and revising this manuscript.

\section{Author's contribution}

AH designed the experiments, guided the entire study, participated in data analysis, wrote and extensively revised this manuscript. SK performed the research and participated in drafting this manuscript. AA initiated the project, guided the study and revised the manuscript. All authors participated in the research and approved the final manuscript.

\section{REFERENCES}

1) Ahmed S, Ahmad M \&Ikram S (2014). Chitosan: a natural antimicrobial agent e a review. Journal of Applicable Chemistry, 3(2), 493e503.

2) Ahmed S, Saifullah, Ahmad M, Swami B, L \&Ikram S (2015). Green synthesis of silver nanoparticles using Azadirachta indica aqueous leaf extract. Journal of Radiation Research and Applied Sciences 9 (2016) 1-7.

3) Alzohairy MA (2016). Therapeutics role of Azadirachta indica (Neem) and their active constituents in diseases prevention and treatment. Evidence- Based Complementary and Alternative Medicine, 2016.

4) Armendariz V, Herrera I, Peralta-Videa JR, Yacaman MJ, Troiani H et al. (2004): Size controlled gold nanoparticle formation by Avena sativa biomass: use of plants in nanobiotechnology. Journal of Nanoparticle Research, 6:377-382.

5) Atawodi, S. E. \&Atawodi, J. C. (2009). Azadirachta indica (neem): a plant of multiple biological and pharmacological activities. Phytochemistry Reviews, 8(3), 601-620.

6) Baklanov MR (2012): In Nanodevices and Nanomaterials for Ecological Security: Chapter 1 Nanoporous Dielectric Materials for Advanced Micro- and Nanoelectronics. Edited by Shunin YN, Kiv AE. The Netherlands: Springer; pp: 3-18.

7) Das S, Das J, Samadder A, Bhattacharyya SS,Das D, et al. (2013): Biosynthesized silver nanoparticles by ethanolic extracts of Phytolacca decandra, Gelsemium sempervirens, Hydrastis canadensis and Thuja occidentalis induce differential cytotoxicity through G2/M arrest in A375 cells. Colloids Surf B Biointerfaces, 101:325-336.

8) Dubey SP, Lahtinen M, Särkkä H, Sillanpää M (2010): Bioprospective of Sorbus aucuparia leaf extract in development of silver and gold nanocolloids. Colloids Surf B Biointerfaces, 80:26-33. 
9) Dubey SP, Lahtinen M, Sillanpää M (2010): Green synthesis and characterizations of silver and gold nanoparticles using leaf extract of Rosa rugosa. Colloids and Surfaces A: Physicochem Eng Aspects, 364:34-41.

10) Dubey SP, Lahtinen M, Sillanpää M (2010): Tanacetum Vulgae (Tansy) fruit mediated greener synthesis of silver and gold nanoparticles. Process Biochem, 45:1065-1071.

11) Dobrucka R, Długaszewska J (2015). Antimicrobial Activities of Silver Nanoparticles Synthesized by Using Water Extract of Arnicae anthodium. Indian journal of Microbiology, doi: 10.1007/s12088-015-0516-x

12) Ericka RL, Ramón IP, Rosa EN, Ronaldo HU, Judith T et al. (2013). Synthesis of silver nanoparticles using reducing agents obtained from natural sources (Rumex hymenosepalus extracts). Rodríguez-León et al. Nanoscale Research Letters, 8:318.

13) Etheridge ML, Campbell SA, Erdman AG, Haynes CL, Wolf SM, et al. (2013). The big picture on nanomedicine: the state of investigational and approved nanomedicine products. Nanomedicine: Nanotechnology, Biology, and Medicine. 8:1-14.doi: 10.1016/j.nano.2012.05.013.

14) Gardea-Torresdey JL, Parsons JG, Gomez E, Peralta-Videa J, Troiani HE et al. (2008): Formation and growth of $\mathrm{Au}$ nanoparticles inside live alfalfa plants. Nano Lett 2002, 2:397-401.

15) Ghoreishi SM, Behpour M, Khayatkashani M (2011): Green synthesis of silver and gold nanoparticles using Rosa damascena and its primary application in electrochemistry. Physica E, 44:97-104.

16) Girish, Shankara (2008).Bioactive compounds found in Neem: A review. Journal of Pharmaceutical Analysis, 6(5), 80-113.

17) Govindachari TR, Suresh G, Gopalakrishnan G, Banumathy B \&Masilamani S (1998).Identification of antifungal compounds from the seed oil of Azadirachta indica . Phytoparasitica ; 26(2):109-116. doi: 10.1007/bf02980677.

18) Hugo WB, Russell AD. Russell AD, Hugo WB, Ayliffe GAJ (1982). Types of antimicrobial agents, Oxford, UK Blackwell Scientific Publications. pp. 8-106.

19) Jotterand F, Alexander AA (2011). In: Biomedical Nanotechnology: Managing the "Known Unknowns": Theranostic Cancer Nanomedicine and Informed Consent. Hurst SJ, editor. Illinois: Springer. pp. 413-430.

20) Kalidindi SB, Jagirdar BR (2012). Nanocatalysis and prospects of green chemistry. ChemSus Chem. 8:65-75.

21) Karni TC, Langer R, Kohane DS (2012). The smartest materials: the future of nanoelectronics in medicine. ACS Nano. 8:6541-6545. doi: 10.1021/nn302915s.

22) Koksharov YA (2009): In Magnetic Nanoparticles: Magnetism of nanoparticles: effects of size, shape and interactions. Edited by Gubin SP. Moscow: Wiley-VCH Verlag; pp: 117196.

23) Kung HH, Kung MC (2007). In: Nanotechnology in Catalysis Vol. 3: Nanotechnology and Heterogeneous Catalysis. Zhou B, Han S, Raja R, Somorjai GA, editor. New York: Springer. pp. 1-11.

24) Kumar VG, Gokavarapu SD, Rajeswari A, Dhas TS, Karthick V et al. (2011): Facile green synthesis of gold nanoparticles using leaf extract of antidiabetic potent Cassia auriculata. Colloids Surf B Biointerfaces, 87:159-163. 
25) Ledwith DM, Aherne D, Kelly JM (2009): In Metallic Nanomaterials Vol. 1: Approaches to the Synthesis and Characterization of Spherical and Anisotropic Silver Nanomaterials. Edited by Kumar SSR. Weinheim: Wiley-VCH Verlag; pp: 99-148.

26) Lee H, Messersmith PB (2007). In: Nanotechnology in Biology and Medicine: BioInspired Nanomaterials for a New Generation of Medicine. Vo-Dinh T, editor. Florida: Taylor and Francis. pp. $1-9$.

27) Lu A, Salabas EL, Schüth F (2007): Magnetic nanoparticles: synthesis, protection, functionalization, and application. Angew ChemInt Ed, 46:1222-1244.

28) Lu W, Lieber CM (2007). Nanoelectronics from the bottom up. Nat Mater:8: 841850.doi: 10.1038/nmat2028.

29) Lugli P, Locci S, Erlen C, Csaba G (2010). In: Nanotechnology for Electronics, Photonics, and Renewable Energy Molecular Electronics: Chapter 1Challenges and Perspectives. Korkin A, Krstic PS, Wells JC, editor. New York: Springer; pp. 1-40.

30) Mata A, Palmer L, Tejeda-Montes E, Stupp SI (2012) In: Nanotechnology in Regenerative Medicine: Chapter 3 Design of Biomolecules for Nanoengineered Biomaterials for Regenerative Medicine. Navarro M, Planell JA, editor. Barcelona: Springer. pp. 39-49.

31) Mitin VV, Kochelap VA, Stroscio MA, editor. Introduction to nanoelectronics: materials for nanoelectronics. UK: Cambridge; 2008. pp. 65-108.

32) Mittal J, Batra A, Singh A, \& Sharma M (2014). Phytofabricationof nanoparticles through plant as nanofactories. Advances in Natural Sciences: Nanoscience and Nanotechnology, doi.org/10.1088/2043-6262/5/4/043002, 043002 .

33) Mohanpuria P, Rana NK, Yadav SK (2008): Biosynthesis of nanoparticles: technological concepts and future applications. J Nanopart Res, 10:507-517.

34) Moyo M, Gomba M \&Nharingo T (2015). Afzelia quanzensis bark extract for green synthesis of silver nanoparticles and study of their antibacterial activity. International Journal of Industrial Chemistry, Volume 6, Issue 4, pp 329-338.

35) Murphy CJ, Sau TK, Gole AM, Orendorff CJ, Gao J, et al. (2005). Anisotropic metal nanoparticles: synthesis, assembly, and optical applications. J PhysChem 109:1385713870.

36) Narayanan KB, Sakthivel N (2011): Green synthesis of biogenic metal nanoparticles by terrestrial and aquatic phototrophic and heterotrophic eukaryotes and biocompatible agents. Adv Colloid Interface Sci, 169:59-79.

37) Niraimathi KL, Sudha V, Lavanya R, Brindha P: Biosynthesis of silver nanoparticles using Alternanthera sessilis (Linn.) extract and their antimicrobial, antioxidant activities. Colloids Surf B Biointerfaces 2013, 102:288-291.

38) Nelson JK (2007): Overview of nanodielectrics: insulating materials of the future. In Proceedings of Electrical Insulation Conference and Electrical Manufacturing Expo, October 2007. Nashville: EEIC; pp: 229.

39) Noruzi M, Zare D, Davoodi D: A rapid biosynthesis route for the preparation of gold nanoparticles by aqueous extract of cypress leaves at room temperature. SpectrochimicaActa Part A 2012, 94:84-88.

40) Parsons JG, Peralta-Videa JR, Gardea-Torresdey JL (2007): In Developments in Environmental Science, Volume 5: Chapter 21 Use of plants in biotechnology: Synthesis 
of metal nanoparticles by inactivated plant tissues, plant extracts, and living plants. Edited by Sarkar D, Datta R, Hanigan R. Minessota: Elsevier; pp: 436-485.

41) Prasad TN \&Elumalai EK (2011). Biofabrication of Ag nanoparticles using Moringa oleifera leaf extract and their antimicrobial activity. Asian Pacific Journal of Tropical Biomedicine, 1(6), 439-442.

42) Satish V Patil, Hemant P Borase, Chandrashekhar D Patil, Chandra BK. Salunke (2012). Biosynthesis of Silver Nanoparticles Using Latex from Few Euphorbian Plants and Their Antimicrobial Potential, Applied Biochemistry and Biotechnology, Volume 167, Issue 4, pp 776-790.

43) Serp P, Philippot K (2013). In: Nanomaterials in Catalysis: Concepts in Nanocatalysis. Serp P, Philippot K, editor. Weinheim: Wiley-VCH Verlag. pp. 1-54.

44) Sivaraman SK, Elango I, Kumar S, Sunthanam VA (2009). A green protocol for room temperature synthesis of silver nanoparticles in seconds. CurrSci 8:1055-1059.

45) Sharma VK, Yngard RA, Lin Y (2009): Silver nanoparticles: green synthesis and their antimicrobial activities. Adv Colloid Interface Sci, 145:83-96.

46) Shankar SS, Ahmad A, Sastry M (2003): Geranium leaf assisted biosynthesis of silver nanoparticles. BiotechnolProg, 19:1627-1631.

47) Shankar SS, Rai A, Ahmed A, Sastry M (2004): Rapid synthesis of Au, Ag, and bimetallic $\mathrm{Au}$ core-Ag shell nanoparticles using Neem (Azadirachta indica) leaf broth. J Colloid Interface Sci, 275:496-502.

48) Shomura Y (2011). In: Advances in Composite Materials for Medicine and Nanotechnology: Composite Material Stent Comprising Metallic and Non-metallic Materials. Aftaf B, editor. Croatia: InTech.pp.59-74.

49) Shen Y, Friend CS, Jiang Y, Jakubczyk D, Swiatkiewicz J et al. (2000). Nanophotonics: interactions, materials, and applications. J PhysChem B; 8: 7577-7587. doi: 10.1021/jp0016131.

50) Singh S, Saikia JP, Buragohain AK (2013): A novel 'green' synthesis of colloidal silver nanoparticles (SNP) using Dillenia indica fruit extract. Colloids Surf B Biointerfaces, 102:83-85.

51) Suriyakalaa U, Antony JJ, Suganya S, Siva D, Sukirtha R, et al. (2013): Hepatocurative activity of biosynthesized silver nanoparticles fabricated using Andrographis paniculata. Colloids Surf B Biointerfaces, 102:189-194.

52) Syafiuddin A, Salim MR, Beng Hong Kueh A, Hadibarata T, \&Nur H (2017). A review of silver nanoparticles: Research trends, global consumption, synthesis, properties, and future challenges. Journal of the Chinese Chemical Society, 64(7), 732-756.

53) Tahany GM, Mohammad AF \&Abd El-Rahman (2015). Environmentally friendly synthesis of silver nanoparticles using Moringa oleifera (Lam) leaf extract and their antibacterial activity against some important pathogenic bacteria. Mycopath (2015) 13(1): 1-6.

54) Taylor A (2008), editor. Nanophotonics: Nanoscale Phenomena Underpinning Nanophotonics. Washington: The National Academies Press. pp. 19-82.

55) Teot L, Maggio G \& Barrett S (2005). The management of wounds using Silvercel hydro alginate. Wounds UK, 1(2), 70. 
56) Tran QH, Van Quy Nguyen VQ, Le AT (2013). Silver nanoparticles: synthesis, properties, toxicology, applications and perspectives. Adv Nat Sci: Nanosci Nanotechnol; 4:1-21.

57) Tripathi A, Chandrasekaran N, Raichur A.M, \& Mukherjee A (2009). Antibacterial applications of silver nanoparticles synthesized by aqueous extract of Azadirachta indica (Neem) leaves. Journal of Biomedical Nanotechnology, 5(1), 93-98.

58) Vankar PS, Shukla D (2012): Biosynthesis of silver nanoparticles using lemon leaves extract and its application for antimicrobial finish on fabric. ApplNanosci, 2:163-168.

59) Weber C, Richter M, Riter S, Knorr A (2008): In Semiconductor Nanostructures: Chapter 9 Theory of the Optical Response of Single and Coupled Semiconductor Quantum Dots. Edited by Bimberg D. Berlin: Springer; pp: 189-210.

60) Yu CH, Tam K, Tsang ESC (2009): In Handbook of Metal Physics, Vol. 5: Chapter 5 Chemical Methods for Preparation of Nanoparticles in Solution. Edited by Blackman J. Amsterdam: Elsevier; pp: 113-141.

61) Zalevsky Z, Mico V, Garcia J (2009). Nanophotonics for optical super resolution from an information theoretical perspective: a review. Journal of Nanophotonics; 8:1-18.

62) Zhang JZ, Wang Z, Liu J, Chen S, Liu G (2004): In Self-Assembled Nanostructures: Chapter 8 Optical, Electronic, and Dynamic Properties of Semiconductor Nanomaterials. Edited by Lockwood DJ. Ontario: Kluwer Academic Publishers; pp: 201-255. 
International Journal of Agriculture, Environment and Bioresearch

Vol. 4, No. 06; 2019

ISSN: $2456-8643$

Table 1: List of bacterial isolates primarily used to test antibacterial activity of crude plant samples

\begin{tabular}{|l|l|}
\hline \multicolumn{1}{|c|}{ Gram positive bacteria } & \multicolumn{1}{|c|}{ Gram negative bacteria } \\
\hline Staphylococcus aureus & Vibrio cholera \\
Micrococcus & Salmonella paratyphi \\
Mycobacterium & S. typhi \\
Epidermidis & Escherichia coli \\
& Proteus vulgaris \\
& Shigella dysenteriae \\
& S. flexneri \\
& Campylobacter \\
\hline
\end{tabular}

Table 2: Antibacterial activity of leaf and bark extracts without Ag-NPs against six bacterial isolates

\begin{tabular}{|c|c|c|c|c|c|c|c|}
\hline \multirow{3}{*}{ 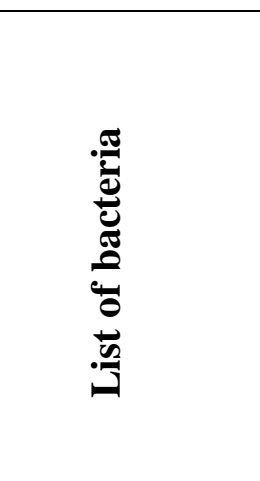 } & \multirow{3}{*}{ 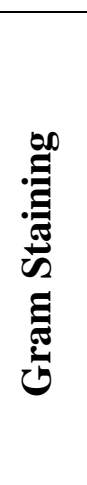 } & \multicolumn{6}{|c|}{ Zone of Inhibition } \\
\hline & & \multicolumn{2}{|c|}{ Neem Leaf (Crude) } & \multicolumn{2}{|c|}{ Neem Bark (Crude) } & \multicolumn{2}{|c|}{ Control } \\
\hline & & $45 \mu \mathrm{g} / \mathrm{disc}$ & $90 \mu \mathrm{g} / \mathrm{disc}$ & $30 \mu \mathrm{g} / \mathrm{disc}$ & $60 \mu \mathrm{g} / \mathrm{disc}$ & $\begin{array}{c}\text { Positive } \\
\text { control } \\
\text { (Ciprofloxaci } \\
\text { n) } \\
(20 \mu \mathrm{g} / \text { disc })\end{array}$ & $\begin{array}{c}\text { Negative } \\
\text { control } \\
\left(\mathrm{DW}^{*}\right)\end{array}$ \\
\hline $\begin{array}{l}\text { Escherichia } \\
\text { coli }\end{array}$ & -ve & $7.42 \pm 0.72$ & $10.17 \pm 0.76$ & $9.17 \pm 0.76$ & $11.50 \pm 2.18$ & $23.00 \pm 2.00$ & n.d ${ }^{* *}$ \\
\hline Micrococcus & $+\mathrm{ve}$ & $6.17 \pm 0.76$ & $10.00 \pm 1.00$ & $7.72 \pm 1.8$ & $13.50 \pm 2.18$ & $28.00 \pm 3.60$ & n.d \\
\hline Vibrio cholera & -ve & $5.72 \pm 0.85$ & $9.5 \pm 1.80$ & $8.25 \pm 1.96$ & $13.83 \pm 1.50$ & $30.00 \pm 1.00$ & n.d \\
\hline $\begin{array}{c}\text { Salmonella } \\
\text { typhi }\end{array}$ & -ve & $7.33 \pm 1.04$ & $11.33 \pm 1.53$ & $5.33 \pm 0.76$ & $9.50 \pm 1.04$ & $30.67 \pm 2.30$ & n.d \\
\hline
\end{tabular}




\section{International Journal of Agriculture, Environment and Bioresearch}

Vol. 4, No. 06; 2019

ISSN: 2456-8643

\begin{tabular}{|cccccccc}
$\begin{array}{c}\text { Staphylococcus } \\
\text { aureus }\end{array}$ & $+\mathrm{ve}$ & $8.33 \pm 0.76$ & $13.00 \pm 1.00$ & $9.50 \pm 1.50$ & $14.83 \pm 2.26$ & $34.33 \pm 2.08$ & n.d \\
$\begin{array}{l}\text { Proteus } \\
\text { vulgaris }\end{array}$ & $-\mathrm{ve}$ & $7.83 \pm 1.76$ & $13.00 \pm 2.00$ & $7.17 \pm 0.76$ & $12.83 \pm 1.26$ & $30.33 \pm 1.53$ & n.d
\end{tabular}

* Distilled Water

** No Dimension

Table 3: Antibacterial activity of leaf and bark extract with Ag-NPs against six bacterial isolates

\begin{tabular}{|c|c|c|c|c|c|c|c|}
\hline \multirow{3}{*}{ 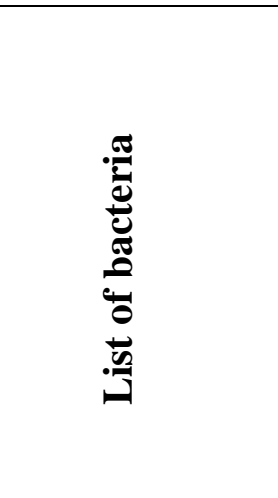 } & \multirow{3}{*}{ 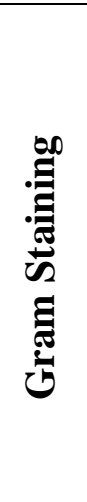 } & \multicolumn{6}{|c|}{ Zone of Inhibition } \\
\hline & & \multicolumn{2}{|c|}{$\begin{array}{c}\text { Ag-NPs From Leaf } \\
\text { extract }\end{array}$} & \multicolumn{2}{|c|}{$\begin{array}{c}\text { Ag-NPs From Bark } \\
\text { extract }\end{array}$} & \multicolumn{2}{|c|}{ Control } \\
\hline & & $45 \mu \mathrm{g} / \mathrm{disc}$ & $90 \mu \mathrm{g} / \mathrm{disc}$ & 30 $\mu \mathrm{g} / \mathrm{disc}$ & $60 \mu \mathrm{g} / \mathrm{disc}$ & 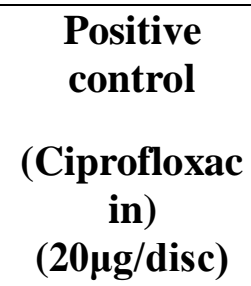 & $\begin{array}{c}\text { Negative } \\
\text { control } \\
\left(\mathrm{DW}^{*}\right)\end{array}$ \\
\hline $\begin{array}{l}\text { Escherichia } \\
\text { coli }\end{array}$ & -ve & $20.67 \pm 2.3$ & $22.00 \pm 1.6$ & $22.00 \pm 1.00$ & $28.00 \pm 2.08$ & $32.00 \pm 2.00$ & n.d** \\
\hline Micrococcus & $+\mathrm{ve}$ & $20.33 \pm 1.7$ & $25.00 \pm 1.00$ & $25.25 \pm 0.58$ & $28.33 \pm 1.00$ & $28.00 \pm 3.60$ & n.d \\
\hline Vibrio cholera & -ve & $24.67 \pm 1.19$ & $26.00 \pm 1.73$ & $24.33 \pm 0.58$ & $28.67 \pm 0.58$ & $33.00 \pm 5.19$ & n.d \\
\hline $\begin{array}{l}\text { Salmonella } \\
\text { typhi }\end{array}$ & -ve & $17.33 \pm 1.33$ & $19.67 \pm 0.33$ & $24.00 \pm 1.00$ & $27.33 \pm 0.58$ & $30.67 \pm 2.30$ & n.d \\
\hline $\begin{array}{c}\text { Staphylococcus } \\
\text { aureus }\end{array}$ & $+\mathrm{ve}$ & $24.33 \pm 1.20$ & $27.33 \pm 1.36$ & $28.00 \pm 2.64$ & $30.00 \pm 2.60$ & $34.33 \pm 2.08$ & n.d \\
\hline $\begin{array}{l}\text { Proteus } \\
\text { vulgaris }\end{array}$ & -ve & $19.50 \pm 0.50$ & $26.75 \pm 0.50$ & $24.00 \pm 1.00$ & $25.67 \pm 2.41$ & $27.33 \pm 1.00$ & n.d \\
\hline
\end{tabular}

* Distilled Water

** No Dimension 
International Journal of Agriculture, Environment and Bioresearch

Vol. 4, No. 06; 2019

ISSN: $2456-8643$

Table 4: MIC value $(\mathrm{mg} / \mathrm{ml})$ of leaf and bark extracts with and without Ag-NPs against 6 test organisms

\begin{tabular}{|l|ccccc|}
\hline Organisms & $\begin{array}{l}\text { Leaf extracts } \\
\text { Crude }\end{array}$ & $\begin{array}{l}\text { Leaf extracts } \\
\text { with Ag-NPs }\end{array}$ & $\begin{array}{l}\text { Bark extracts } \\
\text { Crude }\end{array}$ & $\begin{array}{l}\text { Bark extracts } \\
\text { with Ag-NPs }\end{array}$ & $\begin{array}{l}\text { Positive Control } \\
\text { (Ciprofloxacin) }\end{array}$ \\
\hline Escherichia coli & 1.25 & 0.312 & 0.625 & 0.156 & 0.00030 \\
Micrococcus & 2.5 & 0.625 & 2.5 & 0.312 & 0.00098 \\
Vibrio cholera & 1.25 & 0.156 & 0.625 & 0.078 & 0.00015 \\
Salmonella typhi & 10.0 & 2.5 & 5.0 & 0.312 & 0.00061 \\
$\begin{array}{l}\text { Staphylococcus } \\
\text { aureus }\end{array}$ & 0.312 & 0.078 & 0.312 & 0.039 & 0.00013 \\
Proteus vulgaris & 0.625 & 0.156 & 1.25 & 0.078 & 0.00049 \\
\hline
\end{tabular}


International Journal of Agriculture, Environment and Bioresearch

Vol. 4, No. 06; 2019

ISSN: $2456-8643$

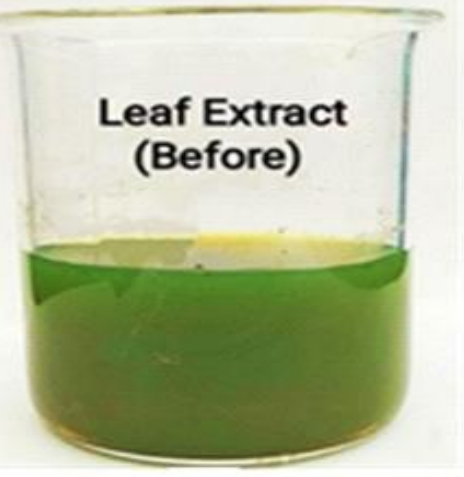

A

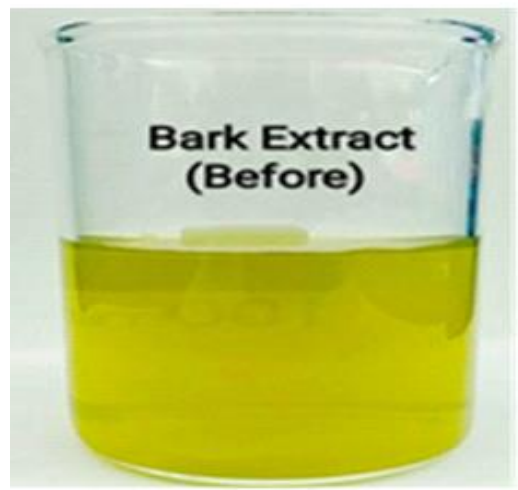

C
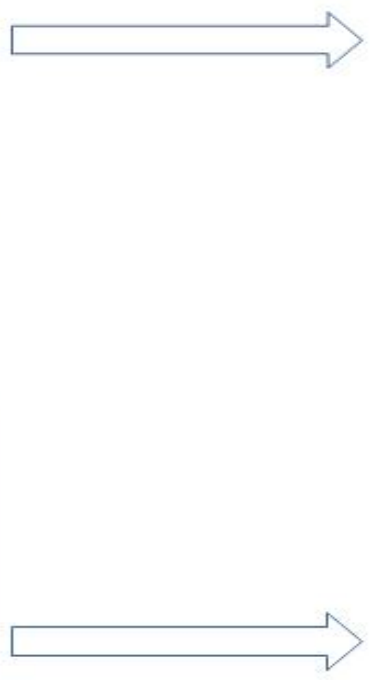

Figure 1: Confirmation of nanoparticle formation by visual observation: Leaf extract before exposure to sunlight (A) and after $30 \mathrm{~min}$ of exposure (B). Similarly bark extract before exposure (C) and after 30 min exposure (D). 
International Journal of Agriculture, Environment and Bioresearch

Vol. 4, No. 06; 2019

ISSN: $2456-8643$

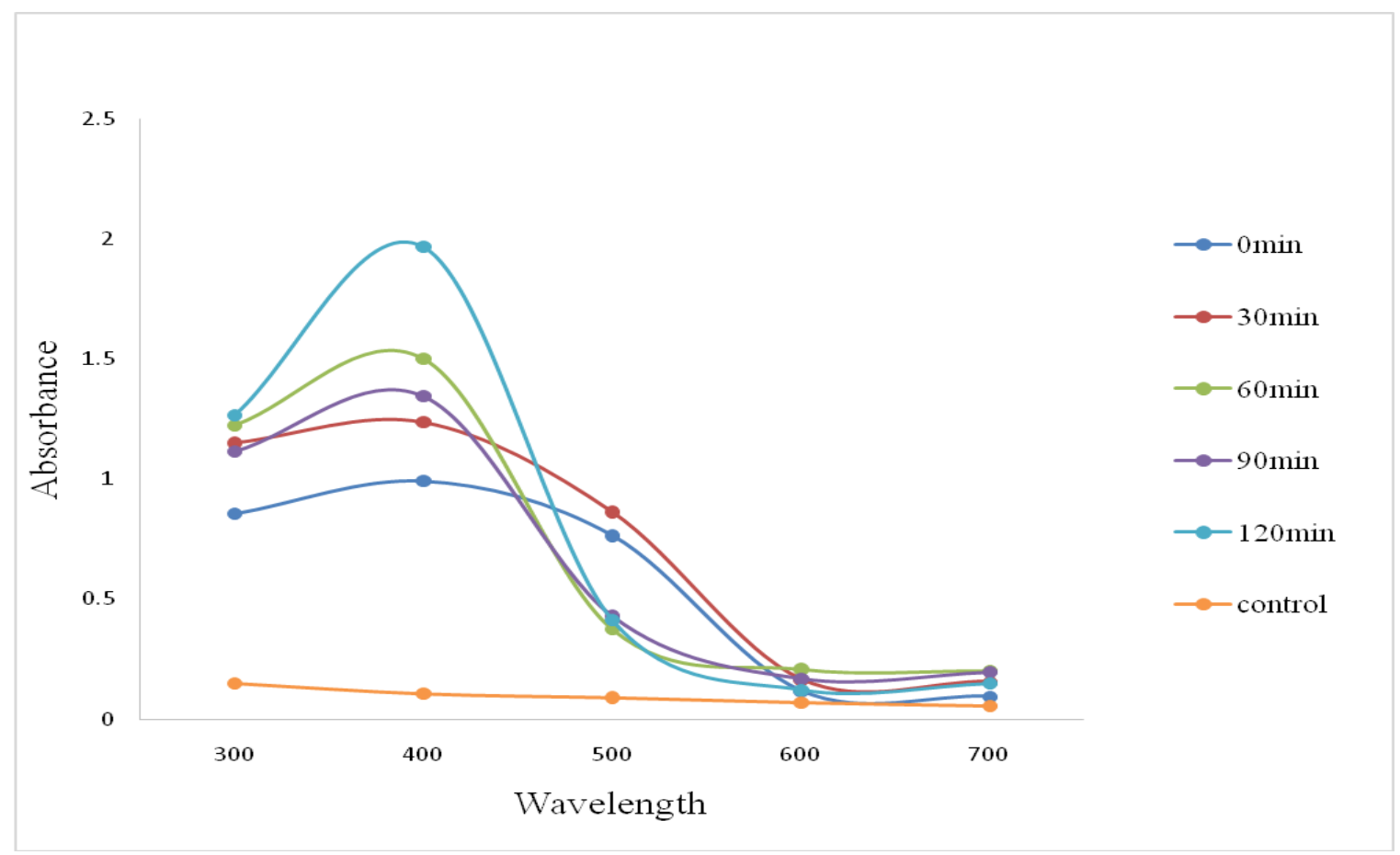

Figure 2: UV-VIS spectral analysis of A. indica leaf extracts and control.

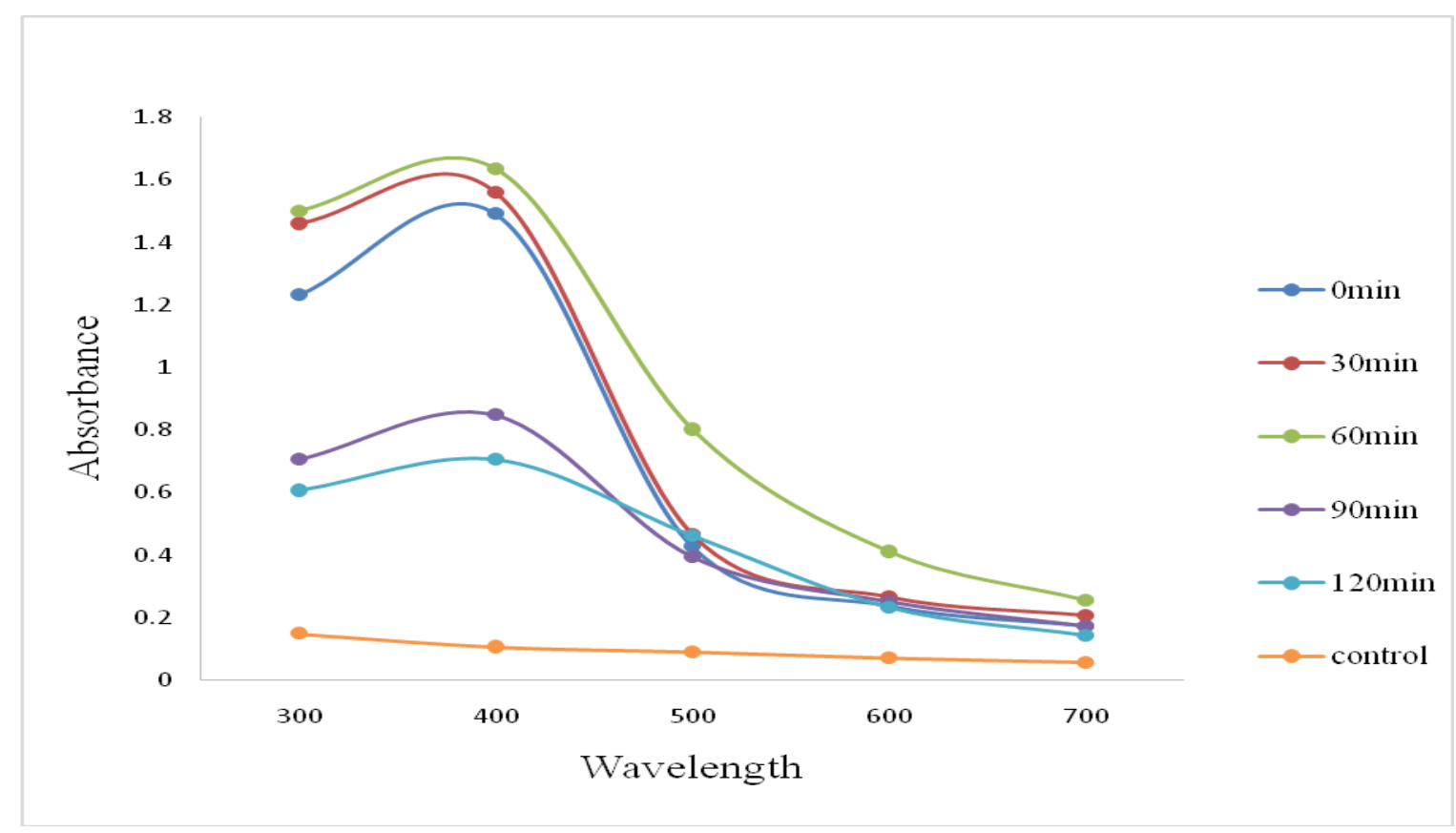

Figure 3: UV-VIS spectral analysis for A. indica bark extracts and control. 


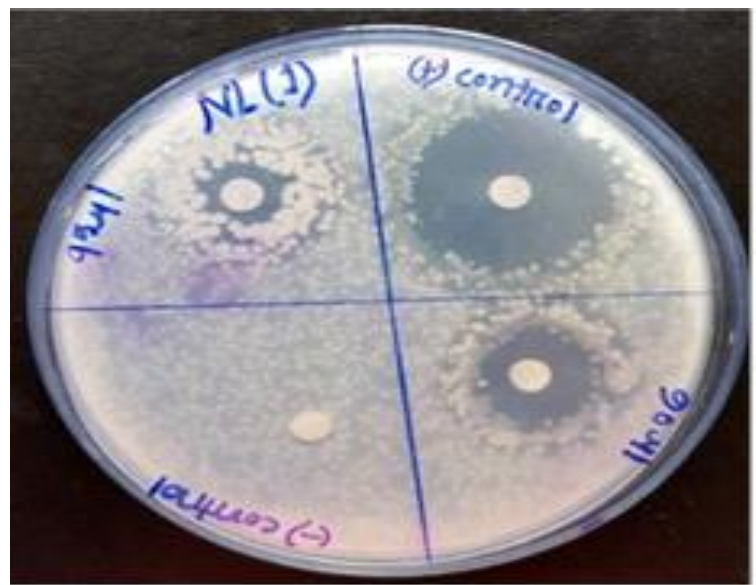

A

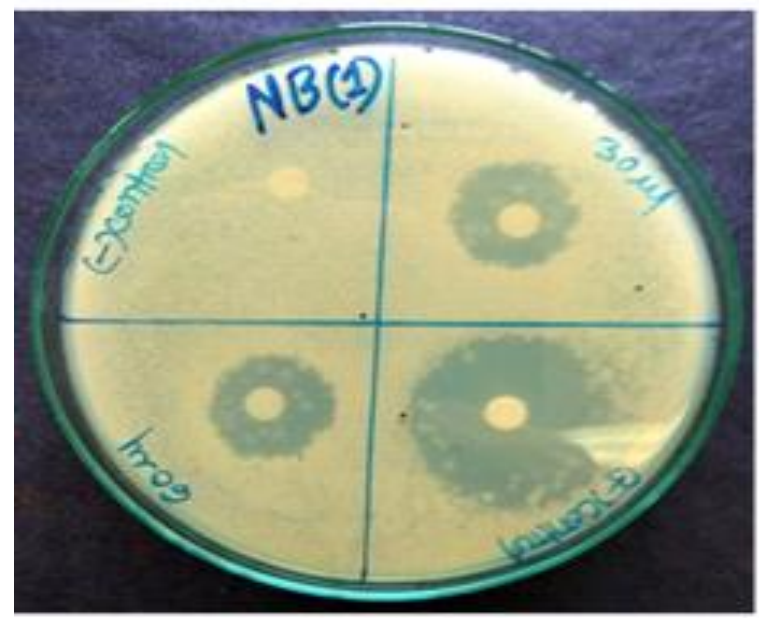

C

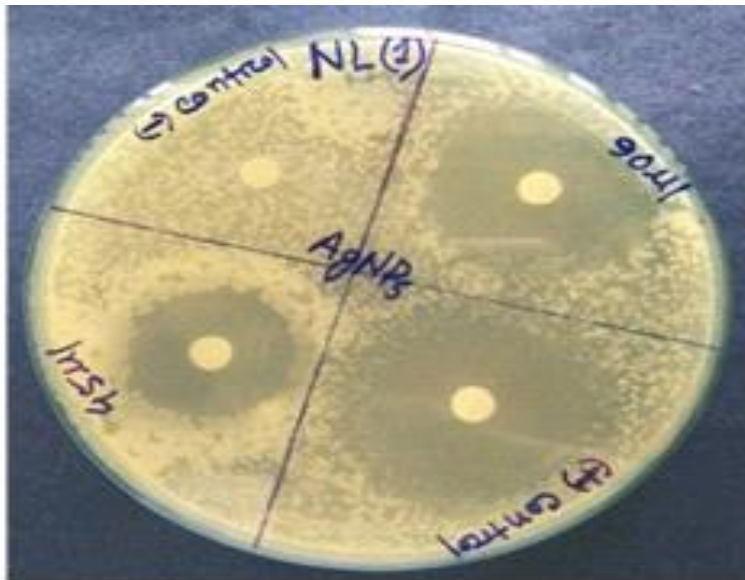

B

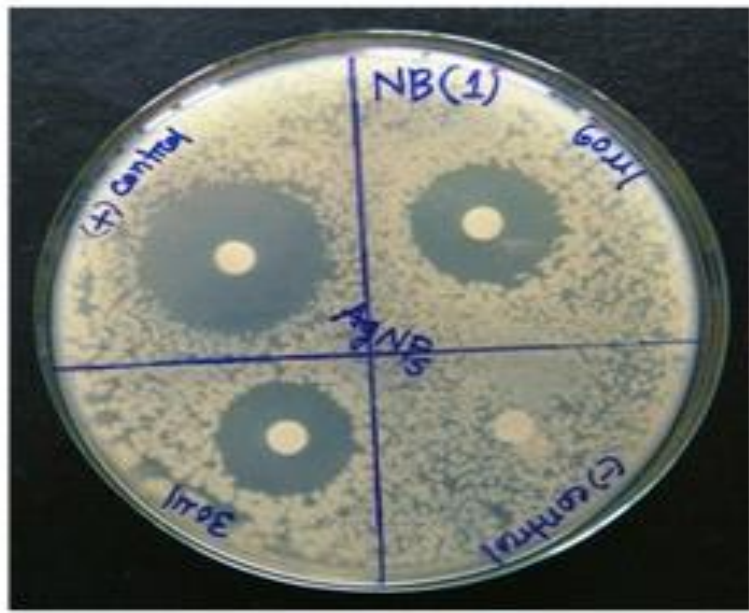

D

Figure 4: Antibacterial activity of leaf and bark extracts of $A$. indica against $E$. coli by disc diffusion method: A) Crude leaf extracts; B) Leaf extracts with Ag-NPs; C) Crude bark extracts and D) Bark extracts with Ag-NPs. 


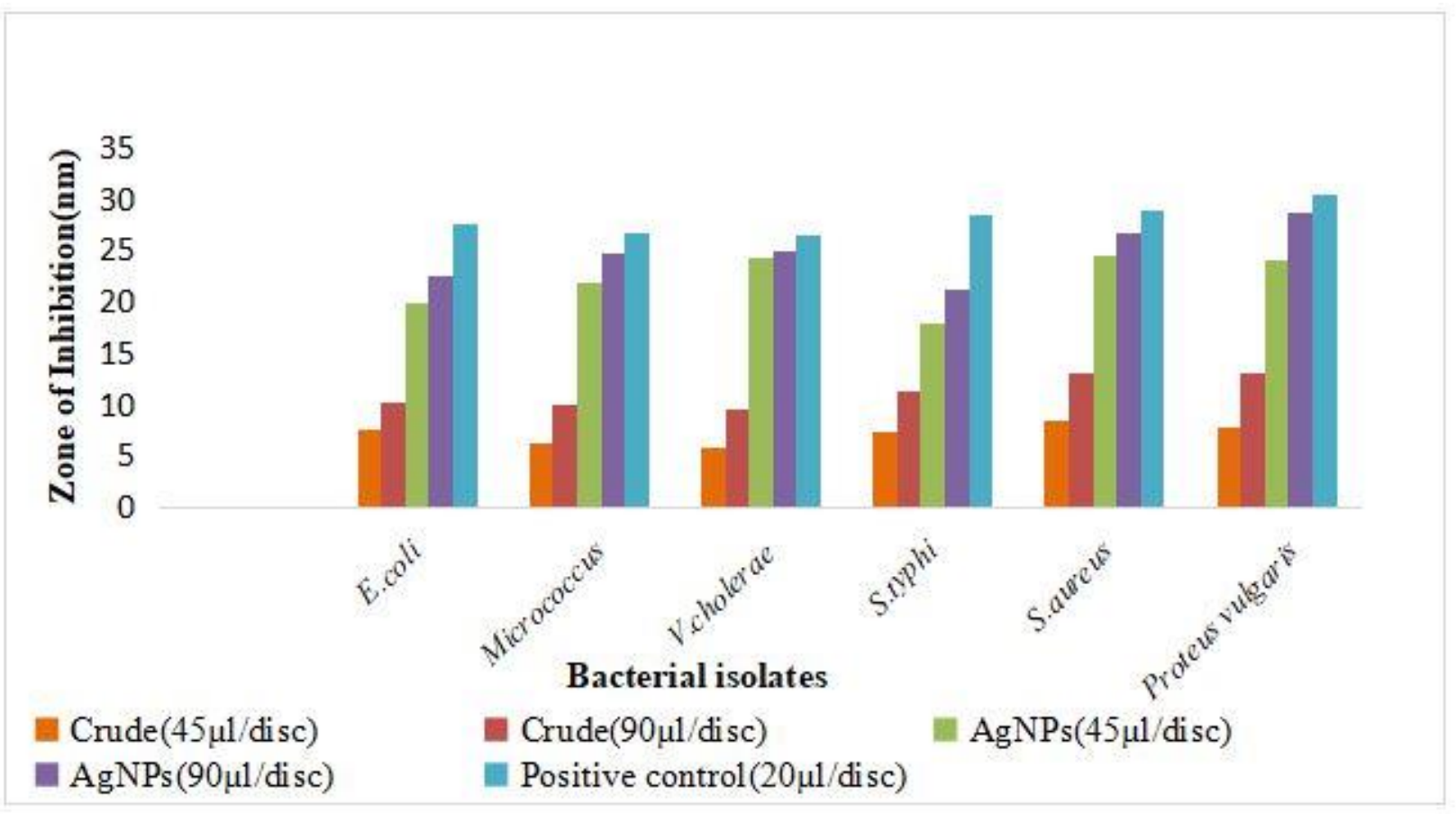

Figure 5: Comparison of the antibacterial activity between crude leaf extract and leaf extract with synthesized Ag-NPs against six bacterial isolates.

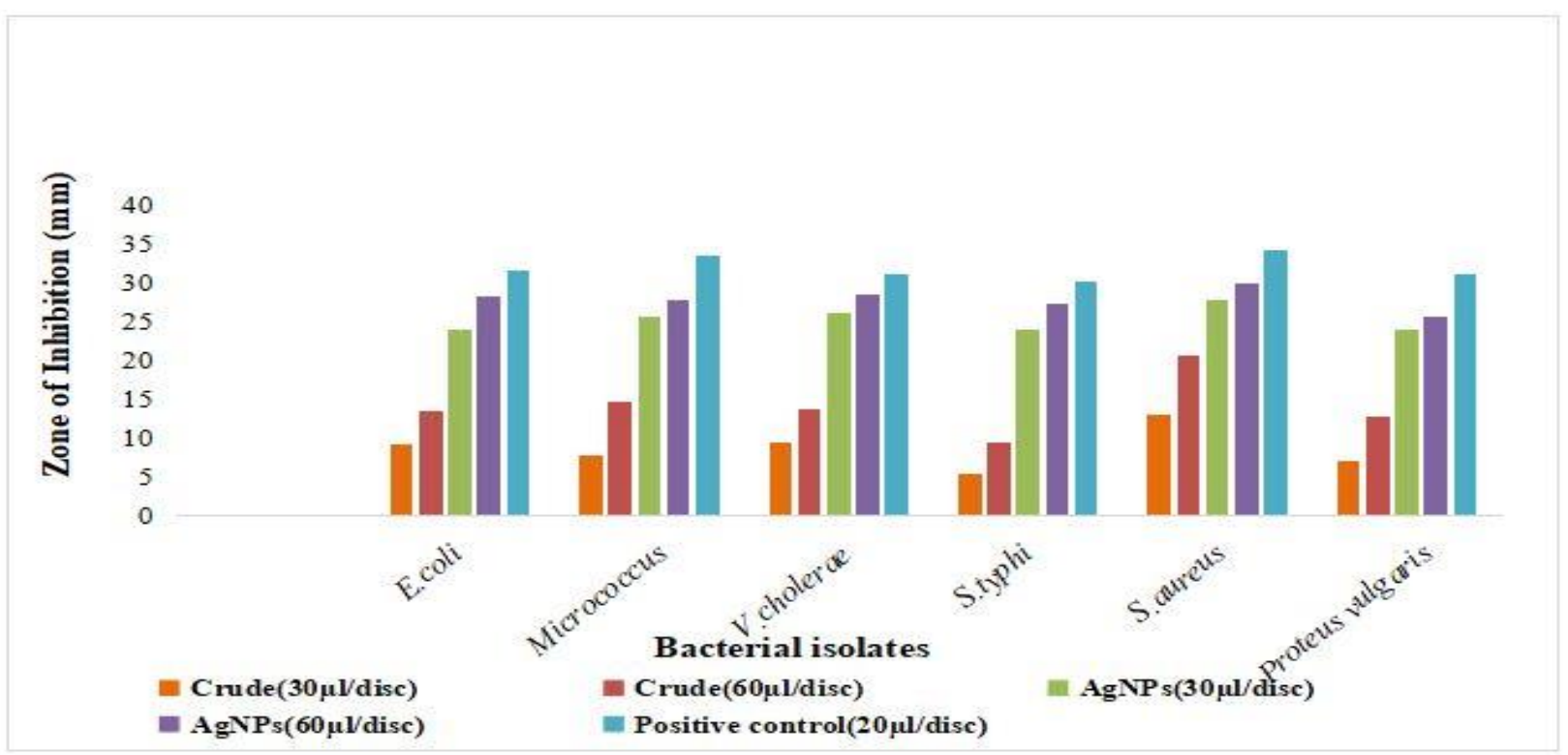

Figure 6: Comparison of the antibacterial activity between crude bark extract and bark extract with synthesized Ag-NPs against six bacterial isolates. 